\title{
Cutaneous Squamous Cell Carcinoma of the Head and Neck Clinical TNM Finding v8
}

National Cancer Institute

\section{Source}

National Cancer Institute. Cutaneous Squamous Cell Carcinoma of the Head and Neck Clinical TNM Finding v8. NCI Thesaurus. Code C133195.

A clinical finding about one or more characteristics of cutaneous squamous cell carcinoma of the head and neck, following the rules of the TNM AJCC v8 classification system. 